\title{
Oral health-related quality of life of preschool children assisted at a University Dental Clinic
}

\section{Qualidade de vida relacionada à saúde bucal em crianças pré-escolares atendidas em uma clínica odontológica universitária}

\author{
Marília Leão Goettems* \\ Raquel Cassol Sisti* \\ Fernanda Burkert Mathias"** \\ Marina Sousa Azevedo** \\ Dione Dias Torriani (in memoriam) (**** $^{* * *}$
}

\begin{abstract}
Objective: This study assessed parental perception on children's oral health-related quality of life (OHRQoL), and children's views on their own teeth. Subjects and method: The sample included in this cross-sectional study consisted of 106 parents and their children, aged 0-6 years, who were assisted at a School of Dentistry. The Early Childhood Oral Health Impact Scale (ECOHIS) was used to assess OHRQoL. Socioeconomic information and reasons for seeking dental care were asked and obtained from parents, while clinical information were collected from files. Children expressed the views on their teeth through an instrument with drawings. Data was analyzed by the Fisher's exact test and Poisson regression. Results: The mean ECOHIS score was 8.31. Higher impacts on $O H R Q o L$ were observed in older children ( $R R=1.75 ; 95 \%$ $C l=1.21-2.54)$, children referred to the clinic due to either dental trauma $(R R=2.44 ; 95 \% \mathrm{Cl}=1.28-4.66)$ or caries $(R R=2.64 ; 95 \% C l=1.39-5.05)$, children who have had caries ( $R R=2.15 ; 95 \% C l=1.50-3.08)$, and children whose parents perceived their own oral health as poor $(R R=1.45$; 95\% Cl=1.02-2.05). Twenty-three (31\%) children expressed dissatisfaction with their oral health. Conclusions: The impact of oral diseases was high for this population. Children whose parents considered their own oral health as regular/poor presented higher impact on quality of life. Moreover, older children, taken to the dentist due to caries or dental trauma, and with previous dental caries experience, presented negative impact on OHRQoL.
\end{abstract}

Keywords: Pediatric dentistry. Quality of life. Oral diseases.

\section{Introduction}

Oral health conditions may affect the daily activities of individuals. Hence, subjective oral health indicators or oral health-related quality of life (OHRQoL) measures have been developed. Such measures complement clinical indicators and provide a better understanding of health of individuals and the community ${ }^{1}$, having important implications for clinical dental practice and dental research ${ }^{2}$.

Specific instruments that consider the child's cognitive, social, and emotional stage have been developed to assess children ${ }^{3,4}$. Thus, studies were performed on occasional, functional, emotional, social, and economic consequences of oral problems in children ${ }^{5,6}$. However, there is still scarce information available on preschool children, mainly in specialized dental services, where the levels of oral diseases are supposed to be higher.

In Brazil, the access of preschoolers to dental care is considered poor, and most children do not go to the dentist at the recommended ages ${ }^{7,8}$. Consequently, children often have their first visit to the dentist because of accidental injuries, such as dental trauma, or because of caries and/or pain ${ }^{9,10}$. Caries and trauma are highly prevalent conditions in primary dentition, and may not only cause symptoms in children, but also have physical, social, and 
psychological influences that interfere in the child's daily routine and quality of life ${ }^{11}$.

Considering that maternal perception on the child's oral health motivates visits to the dentist ${ }^{12}$, it is important to assess parental perception on OHRQoL. It is also possible to obtain valid and reliable information from children, concerning their OHRQoL, through appropriate techniques ${ }^{13}$. Thus, this study aimed to assess parental perception on children's OHRQoL, at a University Dental Clinic, according to socioeconomic and clinical variables, and children's perception on their own oral condition.

\section{Subjects and method}

This study was approved by the Human Research Ethics Committee of the Federal University of Pelotas, RS, Brazil, under protocol number 220/2011. Parents were asked to sign an Informed Consent Form prior to their participation.

Parents and their children, aged 0-6 years, seeking dental care at the Children's Clinic at the School of Dentistry, in Pelotas, RS, Brazil, were invited to participate. Children with any physical or mental conditions were not included in this study. Data were collected by one single evaluator, between August 2011 and April 2012, and included interviews with parents, information about children's perception on their own teeth, and clinical information collected from patient records.

Parental report on the reasons for seeking dental care for the children was obtained. Parental perception on their own OHRQoL was measured by the Brazilian version of the Early Childhood Oral Health Impact Scale (ECOHIS) ${ }^{3,14,15}$. This specifically developed instrument is considered valid and reliable for the assessment of preschoolers. It includes 13 questions, 9 of which assess the impact of oral health problems on children (child section), and 4 of which assess the same impact on the family (family section). The section for child impact includes 4 descriptive domains (symptomatology, and functional, psychological, and self-image/social interaction), and the section for family impact includes 2 domains (parental distress and family function). The answers were provided by a Likert-like scale ( $0=$ Never; $1=$ Hardly ever; $2=$ Occasionally; $3=$ Often; $4=$ Very Often; $5=$ Undecided). Whenever parents answered with numbers 1 to 4 , the reason for impact perceived was requested. Mean scores were calculated for each domain and for the whole scale as a simple sum of response codes, after "Undecided" responses were recoded as missing. The total score presented a 0-52 range: the higher the score, the greater the impact of oral health problems and related treatment experiences on OHRQoL of preschool children and their families. Socioeconomic characteristics were assessed by a questionnaire from the Brazilian Association of Research Institutes ${ }^{16}$.
The Autoquestionnaire Qualité de Vie Enfant Imagé (AUQUEI), adapted by Feitosa, et al. ${ }^{17}$ (2005), was applied to children aged 4 to 6 years, to assess their oral health perception. This instrument consists of a series of pictures where the child is asked to indicate the "sad" and "happy" drawings as a response to the question: How do you feel when you think of your teeth? (Figure 1).
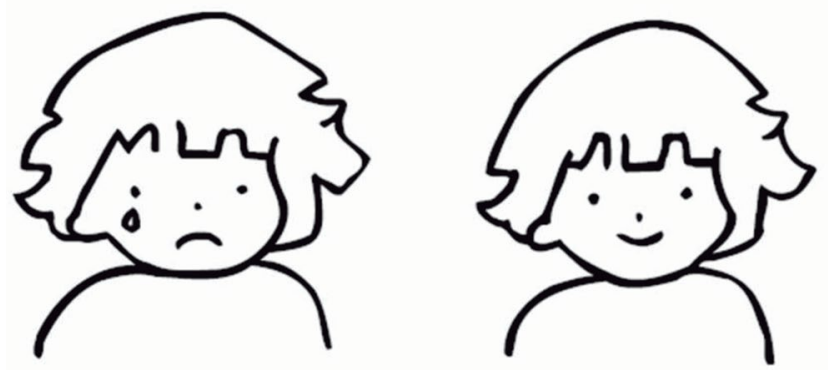

Figure 1 - Faces of Autoquestionnarie Qualité de Vie Enfant Image

Clinical data of the children were collected from patient records, including: presence of dental caries, history of dental trauma, and dental treatments performed.

Descriptive analysis was performed to assess the frequencies of ECOHIS responses and reasons reported by parents to the presence of impact, for each item. The differences among total score means, according to reason for seeking dental care, and clinical and socioeconomic characteristics were compared by the adjusted Poisson regression analysis. This strategy allowed estimating relative risks (RR) between comparison groups and their respective $95 \%$ confidence interval (CI). Fisher's exact test was used for the association between the reason for seeking dental care and AUQUEI results. All analyses were performed at a minimum $5 \%$ significance level, using the software Stata 12.0.

\section{Results}

One hundred and six parents/caretakers, mostly mothers (97\%), were interviewed. The response rate reached $100 \%$. A total of 62 respondents (59\%) were male. Children's age ranged from 13 to 83 months (average of 57.4 months). From the children included in this study, 53 (50\%) were referred to the School of Dentistry due to dental trauma, and $32(30 \%)$ due to caries. As to socioeconomic level, 39 (37\%) of the families were classified as socioeconomic classes $\mathrm{A} / \mathrm{B}$, and 67 (63\%) as classes C/D (Table 1). 


\begin{tabular}{|c|c|c|c|}
\hline Variable & Categories & $N^{*}$ & $\%$ \\
\hline \multicolumn{4}{|c|}{ Child's characteristics } \\
\hline \multirow{2}{*}{ Gender } & Male & 62 & 59 \\
\hline & Female & 44 & 42 \\
\hline \multirow{6}{*}{ Age (months) } & $12-23$ & 7 & 7 \\
\hline & $24-35$ & 12 & 11 \\
\hline & $36-47$ & 13 & 12 \\
\hline & $48-59$ & 17 & 16 \\
\hline & $60-71$ & 25 & 24 \\
\hline & $72-83$ & 32 & 30 \\
\hline \multicolumn{4}{|c|}{ Characteristics of parents/Caretakers } \\
\hline \multirow{2}{*}{ Socioeconomic class } & A-B & 39 & 37 \\
\hline & C-D & 67 & 63 \\
\hline \multirow{2}{*}{ Oral health status rating } & Excellent/good & 52 & 49 \\
\hline & Regular/bad & 54 & 51 \\
\hline \multirow{4}{*}{ Reason for seeking dental care } & Routine visit & 7 & 7 \\
\hline & Dental trauma & 53 & 50 \\
\hline & Dental caries & 40 & 38 \\
\hline & Orthodontic treatment & 6 & 5 \\
\hline \multirow{2}{*}{ Dental caries } & Absent & 50 & 49 \\
\hline & Present & 52 & 51 \\
\hline \multirow{2}{*}{ Dental trauma } & Absent & 53 & 51 \\
\hline & Present & 50 & 49 \\
\hline \multirow{2}{*}{ Orthodontic treatment } & No & 91 & 89 \\
\hline & Yes & 11 & 11 \\
\hline \multirow{2}{*}{ Dental extraction } & No & 86 & 84 \\
\hline & Yes & 16 & 16 \\
\hline
\end{tabular}

The ECOHIS global score varied from 0 to 39 , with mean of $8.31( \pm 7.67)$. No questionnaires missed more than the maximum of "undecided" responses, and none was excluded. Table 2 shows the frequency of impacts by each ECOHIS question, and the reason parents reported for the impact. The item of "pain" was most often reported on the section of child impacts. In the family section, the item of "being upset" was most often reported. Dental pain was the main reason reported for the impact perceived. 
Table 2 - Frequencies of ECOHIS responses and reasons for the impact $(n=106)$

\begin{tabular}{|c|c|c|c|c|c|c|c|}
\hline \multirow{2}{*}{ Item } & \multicolumn{5}{|c|}{ ECOHIS response $\mathrm{N}(\%)$} & \multirow{2}{*}{ Reason } & \multirow{2}{*}{$\mathrm{N}(\%)$} \\
\hline & Never & Hardly ever & Ocasionally & Often & Very often & & \\
\hline $\begin{array}{l}\text { 1. How often has your child had pain } \\
\text { in the teeth, mouth or jaws? }\end{array}$ & $43(41)$ & $22(20)$ & $31(29)$ & $8(8)$ & $2(2)$ & $\begin{array}{l}\text { Caries } \\
\text { Trauma } \\
\text { Other }\end{array}$ & $\begin{array}{r}33(52) \\
25(40) \\
5(8)\end{array}$ \\
\hline \multicolumn{8}{|c|}{ How often has your child.... because of dental problems or dental treatments? } \\
\hline $\begin{array}{l}\text { 2. had difficulty drinking hot or cold } \\
\text { beverages }\end{array}$ & $75(71)$ & $9(9)$ & $15(14)$ & $6(6)$ & $1(1)$ & $\begin{array}{l}\text { Pain } \\
\text { Caries } \\
\text { Trauma } \\
\text { Other } \\
\end{array}$ & $\begin{array}{r}14(45) \\
5(16) \\
8(26) \\
4(13)\end{array}$ \\
\hline 3. had difficulty eating some foods & $54(51)$ & $16(15)$ & $20(19)$ & $14(13)$ & $2(2)$ & \begin{tabular}{|l} 
Pain \\
Caries \\
Trauma \\
Other \\
\end{tabular} & $\begin{array}{r}28(53) \\
4(8) \\
17(33) \\
3(6) \\
\end{array}$ \\
\hline $\begin{array}{l}\text { 4. had difficulty pronouncing any } \\
\text { words }\end{array}$ & $87(82)$ & $6(6)$ & $6(6)$ & $4(4)$ & $2(2)$ & $\begin{array}{l}\text { Pain } \\
\text { Crooked } \\
\text { teeth } \\
\text { Trauma } \\
\text { Other } \\
\end{array}$ & $\begin{array}{r}8(47) \\
1(6) \\
4(23) \\
4(24)\end{array}$ \\
\hline $\begin{array}{l}\text { 5. missed preschool, daycare or } \\
\text { school }\end{array}$ & $85(81)$ & $10(9)$ & $10(9)$ & - & $1(1)$ & $\begin{array}{l}\text { Pain } \\
\text { Trauma } \\
\text { Other } \\
\end{array}$ & $\begin{array}{r}12(55) \\
6(27) \\
4(18)\end{array}$ \\
\hline 6. had trouble sleeping & $78(74)$ & $10(9)$ & $15(14)$ & $3(3)$ & - & $\begin{array}{l}\text { Pain } \\
\text { Caries } \\
\text { Trauma } \\
\text { Other }\end{array}$ & $\begin{array}{r}22(79) \\
1(4) \\
1(4) \\
4(14)\end{array}$ \\
\hline 7. been irritable or frustrated & $60(57)$ & $16(15)$ & $23(21)$ & $6(6)$ & $1(1)$ & $\begin{array}{l}\text { Pain } \\
\text { Esthetic } \\
\text { Carie } \\
\text { Trauma } \\
\text { Other } \\
\end{array}$ & $\begin{array}{r}21(45) \\
1(2) \\
1(2) \\
3(7) \\
20(44) \\
\end{array}$ \\
\hline $\begin{array}{l}\text { 8. avoided smiling or laughing when } \\
\text { around other children }\end{array}$ & $80(75)$ & $5(5)$ & $13(12)$ & $7(7)$ & $1(1)$ & $\begin{array}{l}\text { Pain } \\
\text { Esthetic } \\
\text { Trauma } \\
\text { Other } \\
\end{array}$ & $\begin{array}{r}4(15) \\
18(69) \\
3(12) \\
1(4)\end{array}$ \\
\hline 9. avoided talking with other children & $90(88)$ & $2(2)$ & $7(7)$ & $3(3)$ & - & \begin{tabular}{|l|} 
Pain \\
Esthetic \\
Caries \\
Trauma \\
Other \\
\end{tabular} & $\begin{array}{r}4(34) \\
5(42) \\
1(8) \\
1(8) \\
1(8) \\
\end{array}$ \\
\hline \multicolumn{8}{|c|}{ How often have you or another family member ...because of your child's dental problems or dental treatments? } \\
\hline 10. been upset & $52(50)$ & $14(13)$ & $25(23)$ & $11(10)$ & $4(4)$ & \begin{tabular}{|l|} 
Pain \\
Estethic \\
Caries \\
Trauma \\
Other \\
\end{tabular} & $\begin{array}{r}10(18) \\
3(6) \\
13(24) \\
20(37) \\
8(15)\end{array}$ \\
\hline 11. felt guilty & $57(53)$ & $10(9)$ & $27(26)$ & $8(8)$ & $4(4)$ & $\begin{array}{l}\text { Pain } \\
\text { Esthetics } \\
\text { Caries } \\
\text { Trauma } \\
\text { Other }\end{array}$ & $\begin{array}{r}5(10) \\
1(2) \\
16(33) \\
20(42) \\
6(13) \\
\end{array}$ \\
\hline 12. taken time off from work & $76(71)$ & $3(3)$ & $18(17)$ & $4(4)$ & $5(5)$ & \begin{tabular}{|l|} 
Pain \\
Trauma \\
Dental visit
\end{tabular} & $\begin{array}{r}1(4) \\
1(4) \\
27(92)\end{array}$ \\
\hline $\begin{array}{l}\text { 13. Has your child had dental } \\
\text { problems that had a financial impact } \\
\text { on family? }\end{array}$ & $100(94)$ & $1(1)$ & $3(3)$ & $2(2)$ & - & $\begin{array}{l}\text { Trauma } \\
\text { Other }\end{array}$ & $\begin{array}{l}1(17) \\
5(83)\end{array}$ \\
\hline
\end{tabular}

In the unadjusted analysis, the ECOHIS score was significantly higher for the following: older children, children from parents who perceived their oral health as regular/poor, children taken to the dentist due to dental caries or trauma instead of prevention, and children with dental caries and previous dental extraction (Table 3). Children with previous orthodontic treatment and being treated for dental trauma had lower ECOHIS scores. After adjustments, higher scores were still associated with children's age, parental self-perception on oral health, reasons for seeking dental care, and presence of dental caries. 
Table 3 - Association between demographic, socioeconomic, clinical and parental self perception about oral health and overall ECOHIS scores. Unadjusted and adjusted Poisson regression analysis. Pelotas/Brazil $(n=106)$

\begin{tabular}{|c|c|c|c|c|c|c|}
\hline Variable & RR & $(95 \% \mathrm{Cl})$ & $\mathrm{P}$ & RR & $(95 \% \mathrm{Cl})$ & $P$ \\
\hline \multicolumn{7}{|c|}{ Demographic } \\
\hline \multicolumn{7}{|l|}{ Gender } \\
\hline Male & 1 & & & & & \\
\hline Female & 0.96 & $(0.83-1.09)$ & .51 & & & \\
\hline \multicolumn{7}{|l|}{ Age (years) } \\
\hline 2 & 1.00 & & & 1.00 & & \\
\hline 3 & 1.53 & $(1.68-2.01)$ & $<0.001$ & 1.62 & $(1.08-2.43)$ & 0.02 \\
\hline 4 & 1.57 & $(1.22-2.03)$ & $<0.001$ & 1.43 & $(0.95-2.16)$ & 0.09 \\
\hline 5 & 1.52 & $(1.97-1.93)$ & $<0.001$ & 1.28 & $(0.80-2.05)$ & 0.30 \\
\hline 6 & 1.95 & $(1.56-2.44)$ & $<0.001$ & 1.75 & $(1.21-2.54)$ & 0.003 \\
\hline \multicolumn{7}{|c|}{ Socioeconomic } \\
\hline \multicolumn{7}{|l|}{ Social class } \\
\hline A-B & 1.00 & & & & & \\
\hline C-D & 1.10 & $(0.96-1.26)$ & 0.18 & & & \\
\hline \multicolumn{7}{|c|}{ Self-percepion } \\
\hline \multicolumn{7}{|l|}{ Parental oral health } \\
\hline Excelent/good & 1.00 & & & 1.00 & & \\
\hline Regular/ bad & 1.49 & $(1.30-1.71)$ & $<0.001$ & 1.45 & $(1.02-2.05)$ & 0.04 \\
\hline \multicolumn{7}{|c|}{ Clinical } \\
\hline \multicolumn{7}{|c|}{$\begin{array}{l}\text { Reason for seeking dental } \\
\text { care }\end{array}$} \\
\hline Routine visit & 1.00 & & & 1.00 & & \\
\hline Dental caries & 3.34 & $(2.43-4.57)$ & $<0.001$ & 2.64 & $(1.39-5.05)$ & 0.003 \\
\hline Dental trauma & 1.96 & $(1.43-2.70)$ & $<0.001$ & 2.44 & $(1.28-4.66)$ & 0.007 \\
\hline \multicolumn{7}{|c|}{ Dental caries } \\
\hline Absent & 1.00 & & & 1.00 & & \\
\hline Present & 2.13 & $(1.84-2.46)$ & $<0.001$ & 2.15 & $(1.50-3.08)$ & $<0.001$ \\
\hline \multicolumn{7}{|c|}{ Dental trauma } \\
\hline Absent & 1.00 & & & & & \\
\hline Present & 0.49 & $(0.43-0.57)$ & $<0.001$ & & & \\
\hline \multicolumn{7}{|c|}{ Orthodontic treatment } \\
\hline No & 1.00 & & & & & \\
\hline Yes & 0.60 & $(0.46-0.80)$ & $<0.001$ & & & \\
\hline \multicolumn{7}{|l|}{ Tooth extraction } \\
\hline No & 1.00 & & & & & \\
\hline Yes & 1.58 & $(1.35-1.86)$ & $<0.001$ & & & \\
\hline
\end{tabular}

RR: Rate Ratio; Cl: confidence interval

Seventy-four children answered about their own oral health perception, wherein $23(31 \%)$ were dissatisfied with their oral health (Table 4). Children taken to the dentist for dental caries treatment showed higher frequency of dissatisfaction than children with dental trauma or children taken for either routine visits or orthodontic treatment.
Table 4 - Association between reason for seeking dental care and child self-perception about oral health $(n=74)$

\begin{tabular}{l|r|r|r|r|r}
\hline \multirow{2}{*}{\multicolumn{1}{c|}{ Reason }} & \multicolumn{2}{|c|}{ Sad } & \multicolumn{2}{c|}{ Happy } & \\
\cline { 2 - 6 } & $N$ & \multicolumn{1}{c|}{$\%$} & \multicolumn{1}{c|}{ \% } & \multicolumn{1}{c}{$P^{*}$} \\
\hline Routine Visit/ & 1 & 9 & 10 & 91 & 0.18 \\
Orthodontics & 8 & 29 & 20 & 71 & \\
Dental trauma & 14 & 40 & 21 & 60 & \\
Caries & 23 & 31 & 51 & 69 & \\
\hline Total & & & & &
\end{tabular}




\section{Discussion}

This study assessed parental perception on children's OHRQoL, as well as the perception of children on their own teeth. Although most children reported to feel happy about their teeth, parents reported a high frequency of impact on the family and on children's quality of life. It was found that those children referred to the clinic due to caries or trauma had a greater impact mean as compared to those referred to the clinic for routine visits. Children who had clinical signs of dental caries showed a higher impact mean when compared to those who had not. Parental self-perception on oral health was associated with OHRQoL.

A total of $86 \%$ of the parents reported their children presented impact for at least one item in the child section, and 74\% reported impact for the family section, such frequencies were higher than those found in other studies ${ }^{3,15,18}$. When the frequency of impact for each ECOHIS item was assessed, "pain in teeth, mouth or jaw" was the most frequently reported item for the child section, followed by the item of "difficulty in eating some foods". This agrees with a study conducted with a sample of preschool children in Hong Kong using the same instrument ${ }^{19}$. In the family section, the item of "being upset" was more often reported followed by "feeling guilty", similar to other studies ${ }^{19,20}$. Dental trauma was the most reported cause of impacts for these items, which may occur because these accidents happen rather unexpectedly and parents have to immediately confront a situation that may involve several dental appointments and absence from work, in addition to witnessing the child's pain ${ }^{21}$. The family financial impact for the question of dental problems showed the lowest rates, which may occur because the treatment children receive at the School of Dentistry is free, thus not financially affecting the family.

The mean overall score for the ECOHIS was 8.31 - higher than other studies ${ }^{22}$. A population-based study performed with a representative sample of preschool children, in the city of Pelotas, found a mean score of $3.3^{23}$. This is probably related to the difference in sickness levels in children assisted at the School of Dentistry, as compared to the general population. Most people seeking dental care - or in the case of children, who are taken by their parents or caretakers - do it because they realize that some kind of damage to their oral condition is interfering with their daily routine; therefore, these people probably have a greater perception of problems originated from their oral condition than does the general population. Similarly, children who sought dental care in another School of Dentistry, in Brazil, had a mean score of $9.21^{20}$.

Score differences according to demographic, socioeconomic, and clinical variables were assessed. A previous study detected sociodemographic varia- tions in ECOHIS scores, which included parents with lower level of education and income, thus presenting children with the poorest $\mathrm{OHRQOL}^{19}$. No differences were detected in the present study, which may be related to the fact that most families referring to the University - a public service - are from the same social class. No significant gender difference was detected. Older children had significantly higher scores, which relates to the cumulative effect of oral diseases. Dental caries, for instance, may present later consequences and impacts, even when inactive.

According to previous studies with preschool children, the presence of dental caries based on clinical examination was strongly associated with the child's OHRQoL ${ }^{17,18,23-25}$. This finding was confirmed when the reason for seeking dental care was considered; parents who affirmed taking the child for caries treatment had the worst ECOHIS scores. This may be attributed to the fact that caries is a major source of pain, and a functional and esthetic mouth disorder ${ }^{26}$. Considering caries is a chronic problem, it tends to cause damages and limitations for longer periods, thus influencing the child's OHRQoL ${ }^{17}$.

The results corroborate a previous study that showed that history of extraction because of tooth caries had more potential for higher ECOHIS scores than people who were not affected by this condition. According to the authors, the explanation for this is that children who had a tooth extracted underwent the entire process of caries lesion, including the pain; also, extractions may be traumatic for young children ${ }^{27}$.

The impact of traumatic dental injuries on quality of life has shown conflicted results. Complicated dental trauma caused significant effects on the quality of life of preschoolers, including pain ${ }^{20}$. In other studies, the presence of dental trauma did not produce a negative impact on the overall quality of life ${ }^{23,28}$. Dental trauma, in spite of being potentially harmful, usually causes limitations, such as laceration, edema, and pain, which tend to disappear within a few days. Berger et al. ${ }^{21}$ (2009), assessed the impact on quality of life of a group of children bearing severe trauma and their families, upon their first dental visit, with follow-up of 6 and 12 months. Parents occasionally reported high-impact scores on the first visit. According to these authors, parents may feel guilty, potentially generating stress in the family. After 6 months, a score decline showed an adaptation to this condition. In the present study, parents often indicated dental trauma as a cause for the impacts perceived, and parents who took their children to the dentist reporting traumatic injuries presented higher scores. However, when children with and without clinical signs of dental trauma were compared in the adjusted analysis, the presence of dental trauma was not associated with the mean ECOHIS score. 
Children's perception on oral health was also collected. A study that compared children bearing severe caries and children without caries, assessed by the same instrument, found that children with caries were often $\mathrm{sad}^{17}$. In the present study, nearly all children who were taken to the dentist for routine visits or orthodontic treatment considered themselves happy. From the children who were taken to the dentist for dental trauma and dental caries, $71 \%$ and $60 \%$ respectively, answered they were happy about their teeth.

For preschoolers, the characteristics of child development transfer the responsibility of reporting oral health impacts to adults ${ }^{3}$. In this study, mothers corresponded to $97 \%$ of the respondents, and this high percentage may be attributed to the fact that mothers usually accompany their children to the dental office, and are used to knowing their general health condition, thus being able to detect the impacts on their children's quality of life better than fathers ${ }^{7,29}$. Despite this existing evidence that parents may provide valid reports of their preschool children's OHRQoL, it is worth mentioning that their perception might be influenced by a series of factors. Unfavorable maternal self-perceived oral health, for example, represented a predictor of children's oral health later in adulthood ${ }^{30}$, and the present study showed that this is associated with the perception on children's OHRQoL.

The results emphasize the need to supplement traditional clinical measures with the data obtained from patients themselves and/or people close to them, who are able to understand their experiences and concerns ${ }^{31}$. Studies at population and service levels should include information about the patients and/or the perception of caretakers on the patients' oral condition, as well as treatments aiming to complement the available knowledge about the impact of oral health condition on the daily routine of children. There are few studies with this age group that could produce firm conclusions regarding the impact of different oral problems on quality of life, including dental caries, trauma, and other problems, such as malocclusion and defects in tooth development. The present study sought to increase knowledge on OHRQoL in a population with high level of diseases.

\section{Conclusion}

The impact of oral diseases on OHRQoL was high for the population studied, and parental self-perception on oral health was associated with children's OHRQoL. It was found that older children had poorer quality of life. Moreover, children who had clinical signs of dental caries showed higher impact than those who had not, and children who were referred to the clinic due to caries or trauma had a greater impact mean than those referred to the clinic for routine visits. This finding was confirmed when considering the reason parents sought dental care: parents who affirmed taking the child for caries treatment had the worst ECOHIS scores. Regarding children's perception, the ones that were taken to the dentist for the treatment of dental caries showed higher frequency of dissatisfaction than the ones who presented dental trauma or were taken to the dentist for either routine visits or orthodontic treatment. This information may help dentists to provide proper care for children and families, considering psychosocial aspects.

\section{Resumo}

Objetivo: este estudo avaliou a percepção dos pais sobre a qualidade de vida relacionada à saúde bucal (QVRSB) de seus filhos e suas impressões sobre os seus próprios dentes. Sujeitos e método: uma amostra de 106 pais e seus filhos de zero a seis anos atendidos na Faculdade de Odontologia foi incluída neste estudo transversal. A escala Early Childhood Oral Health Impact (ECOHIS) foi utilizada para avaliar a QVRSB. Informações socioeconômicas e razões do atendimento foram solicitadas e obtidas por intermédio dos pais, e as informações clínicas foram coletadas dos arquivos. As crianças expressaram suas impressões sobre seus dentes por meio de um instrumento com desenhos. Teste exato de Fisher e regressão de Poisson foram utilizados para a análise dos dados. Resultados: a pontuação média do ECOHIS foi de 8,31. Maiores impactos na QVRSB foram observados em crianças mais velhas $(R R=1,75$; IC $95 \%=1,21-2,54)$, crianças encaminhadas para a clínica devido ao trauma dentário $(R R=2,44 ; / C 95 \%=$ 1,28-4,66) ou cáries $(R R=2,64 ;$ IC95\% =1,39-5,05), que tiveram cáries $(R R=2,15$; IC $95 \%=1,50-3,08)$ e aquelas cujos pais consideraram a sua própria saúde bucal como precária $(R R=1,45$; IC 95\% =1,02 -2,05). Vinte e três $(31 \%)$ crianças manifestaram insatisfação com a sua saúde bucal. Conclusões: o impacto das doenças bucais foi alto para a população pesquisada. Crianças cujos pais consideraram sua saúde bucal como regular/ruim apresentaram maior impacto na qualidade de vida. Além disso, crianças mais velhas, que foram levadas ao dentista devido à cárie ou a trauma dentário e com experiência de cárie apresentaram impacto negativo na $Q V R S B$.

Palavras-chave: Odontopediatria. Qualidade de vida. Odontopatias.

\section{References}

1. Jokovic A, Locker D, Stephens M, Kenny D, Tompson B, Guyatt G. Validity and reliability of a questionnaire for measuring child oral-health-related quality of life. J Dent Res 2002;81(7):459-63.

2. Sischo L, Broder HL. Oral health-related quality of life: what, why, how, and future implications. J Dent Res 2011;90(11):1264-70.

3. Pahel BT, Rozier RG, Slade GD. Parental perceptions of children's oral health: the Early Childhood Oral Health Im- 
pact Scale (ECOHIS). Health Qual Life Outcomes 2007;5 (6): $1-10$.

4. Jokovic A, Locker D, Tompson B, Guyatt G. Questionnaire for measuring oral health-related quality of life in eight- to ten-year-old children. Pediatr Dent 2004; 26: 512-518.

5. Tesch FC, Oliveira BH, Leao A. Measuring the impact of oral health problems on children's quality of life: conceptual and methodological issues. Cad Saude Publica 2007;23(11):255564.

6. Allison PJ, Li S, Veronneau J, Loingnon M-C. A Longitudinal Study of Oral Health Related Impacts in Infants. In: IADR/AADR/CADR 86th General Session and Exhibition: 2008; Toronto. [acesso em 2 jul 2015]. Available from URL: https://iadr.confex.com/iadr/2008Toronto/techprogram/abstract_108771.htm

7. Barros AJD, Bertoldi AD. Desigualdades na utilização e no acesso a serviços odontológicos: uma avaliação em nível nacional Ciência e saúde coletiva 2002;7(4):709-17.

8. Kramer PF, Ardenghi TM, Ferreira S, Fischer Lde A, Cardoso L, Feldens CA. [Use of dental services by preschool children in Canela, Rio Grande do Sul State, Brazil]. Cad Saude Publica 2008;24(1):150-6.

9. Lygidakis NA, Marinou D, Katsaris N. Analysis of dental emergencies presenting to a community paediatric dentistry centre. Int J Paediatr Dent 1998;8(3):181-90.

10. Malik-Kotru G, Kirchner L, Kisby L. An analysis of the first dental visits in a Federally Qualified Health Center in a socio economically deprived area. J Clin Pediatr Dent 2009;33(3):265-8.

11. McGrath C, Broder H, Wilson-Genderson M. Assessing the impact of oral health on the life quality of children: implications for research and practice. Community Dent Oral Epidemiol 2004;32(2):81-5.

12. Goettems ML, Ardenghi TM, Demarco FF, Romano AR, Torriani DD. Children's use of dental services: influence of maternal dental anxiety, attendance pattern, and perception of children's quality of life. Community Dent Oral Epidemiol 2012;40(5):451-8.

13. Barbosa TS, Gaviao MB. Oral health-related quality of life in children: part I. How well do children know themselves? A systematic review. Int J Dent Hyg 2008;6(2):93-9.

14. Tesch FC, de Oliveira BH, Leao A. Semantic equivalence of the Brazilian version of the Early Childhood Oral Health Impact Scale. Cad Saude Publica 2008;24(8):1897-909.

15. Scarpelli AC, Oliveira BH, Tesch FC, Leão AT, Pordeus IA, Paiva SM. Psychometric properties of the Brazilian version of the Early Childhood Oral Health Impact Scale (B-ECOHIS). BMC Oral Health 2011;11:19-23.

16. Associação Brasileira de Empresas de Pesquisa Critério de Classificação Econômica Brasil [Internet]. 2006 [acesso em 7 out 2008]. Available from URL: http://www.abep.org/codigosguias/ABEP_CCEB.pdf.

17. Feitosa S, Colares V, Pinkham J. The psychosocial effects of severe caries in 4-year-old children in Recife, Pernambuco, Brazil. Cad Saude Publica 2005;21(5):1550-6.

18. Wandera M, Kayondo J, Engebretsen IM, Okullo I, Astrom AN. Factors associated with caregivers' perception of children's health and oral health status: a study of 6- to 36-month-olds in Uganda. Int J Paediatr Dent $2009 ; 19(4): 251-62$.

19. Wong HM, McGrath CP, King NM, Lo EC. Oral health-related quality of life in Hong Kong preschool children. Caries Res 2011;45(4):370-6.

20. Aldrigui JM, Abanto J, Carvalho TS, Mendes FM, Wanderley MT, Bönecker M, et al. Impact of traumatic dental injuries and malocclusions on quality of life of young children. Health Qual Life Outcomes 2011; 9:78-84.

21. Berger TD, Kenny DJ, Casas MJ, Barrett EJ, Lawrence HP. Effects of severe dentoalveolar trauma on the quality-of-life of children and parents. Dent Traumatol 2009;25(5):462-9.

22. Divaris K, Lee JY, Baker AD, Vann WF. Caregivers' oral health literacy and their young children's oral health-related quality-of-life. Acta Odontol Scand 2012;70(5):390-7.

23. Goettems ML, Ardenghi TM, Romano AR, Demarco FF, Torriani DD. Influence of maternal dental anxiety on oral health-related quality of life of preschool children. Qual Life Res 2011;20(6):951-9.

24. Low W, Tan S, Schwartz S. The effect of severe caries on the quality of life in young children. Pediatr Dent 1999;21(6):325-6.

25. Filstrup SL, Briskie D, da Fonseca M, Lawrence L, Wandera A, Inglehart MR. Early childhood caries and quality of life: child and parent perspectives. Pediatr Dent 2003;25(5):431-40.

26. Antunes JLF, Peres MA, Mello TRC. Determinantes individuais e contextuais da necessidade de tratamento odontológico na dentição decídua no Brasil. Ciênc saúde coletiva 2006;11(1):79-87.

27. Leal SC, Bronkhorst EM, Fan M, Frencken JE. Untreated cavitated dentine lesions: impact on children's quality of life. Caries Res 2012;46(2):102-6.

28. Abanto J, Carvalho TS, Mendes FM, Wanderley MT, Bönecker M, Raggio DP.Impact of oral diseases and disorders on oral health-related quality of life of preschool children. Community Dent Oral Epidemiol 2011;39(2):105-14.

29. Pani SC, Badea L, Mirza S, Elbaage N. Differences in perceptions of early childhood oral health-related quality of life between fathers and mothers in Saudi Arabia. Int J Paediatr Dent 2012;22(4):244-9.

30. Shearer DM, Thomson WM, Broadbent JM, Poulton R. Maternal oral health predicts their children's caries experience in adulthood. J Dent Res 2011;90(5):672-7.

31. Fitzpatrick R, Davey C, Buxton MJ, Jones DR. Evaluating patient-based outcome measures for use in clinical trials. Health Technol Assess 1998;2(14):i-iv, 1-74.

\section{Correspondence address:}

Marília Leão Goettems

Faculdade de Odontologia

Universidade federal de Pelotas

Rua Gonçalves Chaves 457, 4ํandar, Centro

96015-560 Pelotas,RS, Brasil

Telefone: 5332226690

E-mail: mariliagoettems@hotmail.com

Recebido: 22/04/15. Aceito: 02/07/15. 